\title{
OCENA WYBRANYCH ZACHOWAŃ ZDROWOTNYCH MLODZIEŻY Z TERENU POLSKI ŚRODKOWO-WSCHODNIEJ
}

\section{ASSESSMENT OF SELECTED HEALTH ACTIVITIES UNDERTAKEN BY TEENAGERS IN EAST-CENTRAL POLAND}

\author{
Ewa Humeniuk $^{1(\mathrm{E}, \mathrm{F})}$, Olga Dąbska ${ }^{1(\mathrm{~B}, \mathrm{E}, \mathrm{F})}$, \\ Katarzyna Pawlikowska-Łagód ${ }^{2(B, D)}$, Marlena Rumińska ${ }^{1(B, C)}$
}

${ }^{1}$ Uniwersytet Medyczny w Lublinie, Wydział Nauk o Zdrowiu, Zakład Patologii i Rehabilitacji Mowy ${ }^{2}$ Uniwersytet Medyczny w Lublinie, Wydział Nauk o Zdrowiu, Zakład Etyki i Filozofii Człowieka

Humeniuk, E., Dąbska, O., Pawlikowska-Łagód, K., Rumińska, M. (2018). Ocena wybranych zachowań zdrowotnych młodzieży z terenu Polski Środkowo-Wschodniej. Rozprawy Społeczne, 12(2), 73-81. https://doi.org/10.29316/rs.2018.14

Wkład autorów:

A. Zaplanowanie badań

B. Zebranie danych

C. Dane - analiza i statystyki

D. Interpretacja danych

E. Przygotowanie artykułu

F. Wyszukiwanie i analiza

literatury

G. Zebranie funduszy
Tabele: 4

Ryciny: 0

Literatura: 30

Otrzymano: maj 2017

Zaakceptowano: czerwiec 2017

\begin{abstract}
Streszczenie
Wstęp. Styl życia to najistotniejszy czynnik wpływający na ludzkie zdrowie. Jego podstawowymi składowymi są prawidłowy sposób odżywiania i podejmowanie aktywności fizycznej. Celem badań była analiza podejmowania aktywności fizycznej i ocena sposobu odżywiania populacji młodzieży z terenu Polski środkowo-wschodniej.

Materiał i metody. Grupę badaną stanowiło 150 uczniów wybranych szkół podstawowych, gimnazjów, liceów z terenu Polski Środkowo-Wschodniej. Posłużono się metodą sondażu diagnostycznego, techniką ankietową. Narzędziem badawczym był autorski kwestionariusz, oceniający poziom realizowanych zachowań zdrowotnych. Do analizy materiału badawczego wykorzystano program STATISTICA 12, Microsoft Office Excel.

Wyniki. Ankietowani stawiali mocno na aktywność fizyczna podejmowanie, której determinował rodzaj szkoły i sytuacja materialna rodziny. Badani wykazywali przeciętny poziom zachowań żywieniowych. Jedli nieregularnie i nieracjonalnie, spożywali zbyt mało warzyw, owoców, nabiału, a za dużo mięsa i dań fast-food.

Wnioski. Należy od najmłodszych lat kształtować w społeczeństwie prozdrowotny styl życia, którego nieodłącznymi elementami są prawidłowy sposób żywienia i aktywność fizyczna, gdyż ma on bardzo duży wpływ na zdrowie oraz rozwój dzieci i młodzieży.
\end{abstract}

Słowa kluczowe: młodzież, aktywność fizyczna, zachowania zdrowotne, zwyczaje żywieniowe

\begin{abstract}
Summary
Introduction. Lifestyle is the most significant factor affecting human health. Its basic components comprise proper ways of eating and being involved in physical activity. The goal of the work was an analysis of physical activity and nutrition assessment in the population of teenagers in EastCentral Poland.

Material and methods. The surveyed group consisted of 150 pupils and students from selected primary schools, secondary schools and high schools in Eastern Poland region. The study was conducted using a diagnostic poll method in the form of survey technique. The research tool was the author's questionnaire assessing the level of undertaken health activities. The analysis of the gathered data was done using STATISTICA 12 statistical software and Microsoft Office Excel. Results. The respondents were often involved in physical activity, which was due to the type of school and family's financial situation. The respondents' level of pro-health activities was medium. They ate irregularly and unreasonably. Further, they ate too little vegetables, fruit and dairy products, and too much meat and too many fast food meals.

Conclusions. It is imperative to shape pro-health lifestyle since childhood. It entails having good eating habits and undertaking physical activity. All this has a significant impact on health and development in children and youth.
\end{abstract}

Keywords: adolescents, physical activity, health attitude, dietary habits

Adres korespondencyjny: Olga Dąbska, Uniwersytet Medyczny w Lublinie, Zakład Patologii i Rehabilitacji Mowy, ul. Staszica 4-6 (Collegium Maximum), 20-081 Lublin, e-mail: olga.dabska@umlub.pl, tel.: +48 814486792

Copyright by: Państwowa Szkoła Wyższa im. Papieża Jana Pawła II w Białej Podlaskiej, Ewa Humeniuk, Olga Dąbska, Katarzyna Pawlikowska-Łagód, Marlena Rumińska

Czasopismo Open Access, wszystkie artykuły udostępniane są na mocy licencji Creative Commons Uznanie autorstwa-użycie niekomercyjne-na tych samych warunkach 4.0 Międzynarodowe (CC BY-NC-SA 4.0, http://creativecommons.org/licenses/by-nc-sa/4.0/). 


\section{Wstęp}

Styl życia uważany jest za najistotniejszy czynnik wpływający na ludzkie zdrowie. Jego podstawowymi składowymi są prawidłowy sposób odżywiania i podejmowanie aktywności fizycznej. Determinanty te kształtują wzrost, rozwój i funkcjonowanie bio-psycho-społeczne (Ambroży, Bester, Czuchraj, Dostał, Dubiel, 2013). Nieodpowiednio zbilansowana dieta i niedostateczny ruch mogą doprowadzić do licznych nieprawidłowości w stanie zdrowia. Dlatego też dąży się do popularyzowania zachowań sprzyjających zdrowiu już od dziecińst wa, gdyż czas ten uważany jest za najbardziej dynamiczny etap w życiu człowieka z racji mającego wówczas miejsce intensywnego rozwoju organizmu. „Ponadto w tym okresie kształtują się i utrwalają zachowania prozdrowotne,, (Wagner i in., 2015, s. 280), które wraz ze zgromadzoną wiedzą i nabytymi umiejętnościami warunkują charakter postaw zdrowotnych na przyszłe dorosłe życie (Bednarek, Bednarz, 2013).

Celem badań była analiza podejmowania aktywności fizycznej i ocena sposobu odżywiania w populacji młodzieży z terenu Polski środkowo-wschodniej.

\section{Materiał i metody}

Grupę badaną stanowiło 150 uczniów wybranych szkół podstawowych (33\%), gimnazjów (33\%) i liceów (34\%) z terenu Polski Wschodniej. Badania przeprowadzono wśród młodzieży uczęszczającej do Zespołu Szkół im. Mikołaja Kopernika w Bełżycach (n=25), Zespołu Szkół nr 2 w Bełżycach $(n=50)$, Szkoły Podstawowej nr 25 im. Władysława Broniewskiego w Lublinie ( $\mathrm{n}=25)$, Gimnazjum nr 18 im. Macieja Rataja w Lublinie $(n=25)$, XXIII Liceum Ogólnokształcącego im. Nauczycieli Tajnego Nauczania w Lublinie ( $\mathrm{n}=25)$.

Ponad połowę (59\%) respondentów stanowiły dziewczęta. Badani reprezentowali grupy wiekowe 10-12 lat (33\%), 13-15 lat (33\%), 16-18 lat (34\%),

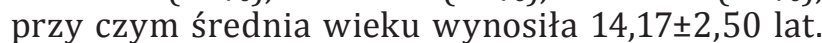
Pochodzenie respondentów rozłożyło się dość proporcjonalnie, gdyż $53 \%$ badanych mieszkało w mieście $(\mathrm{n}=80)$, a $47 \%$ na wsi $(\mathrm{n}=70)$. Średnia wartość współczynnika BMI w badanej grupie młodzieży wyniosła 19,36 $\pm 3,15$. Ankietowani mieli przeważnie $(77 \%)$ prawidłową masę ciała. U pozostałych badanych wskazano na niedowagę (11\%), nadwagę (8\%) czy otyłość (4\%). Badanych poproszono o dokonanie oceny sytuacji materialnej rodziny. Przeważnie (45\%) oceniono ją, jako dobrą bądź bardzo dobrą (35\%).

Przeprowadzając badania posłużono się metodą sondażu diagnostycznego, techniką ankietową. Narzędziem badawczym był autorski kwestionariusz, oceniający częstość podejmowania wysiłku fizycznego, ulubione formy ruchu, liczbę spożywanych dziennie posiłków oraz ich skład pokarmowy. Narzędzie składało się z pytań zamkniętych w formie alternatywnych i koniunktywnych. Ankietę opatrzono metryczką z pytaniami o czynniki socjo-demograficzne. Badania miały charakter dobrowolny, indywidualny, anonimowy i zostały zrealizowane zgodnie z założeniami Deklaracji Helsińskiej. Procedurę ankietowania przeprowadzono podczas zajęć godziny wychowawczej. Analizy materiału badawczego dokonano przy użyciu pakietu statystycznego STATISTICA 12 i programu Microsoft Office Excel. Przyjęto poziom istotności $\mathrm{p}<0,05$, wskazujący na istotne statystycznie różnice bądź zależności. Posłużono się testem $\mathrm{Chi}^{2}$.

\section{Wyniki}

Badani wykazali duże zainteresowanie aktywnością fizyczną. Młodzież ćwiczyła głównie 2-3 razy $(34 \%), 4-5$ razy $(30 \%)$ oraz $6-7$ razy $(21 \%)$ tygodniowo. Najczęściej podejmowaną formą ruchu była jazda na rowerze (51\%), spacery (43\%), bieganie $(35 \%)$, piłka nożna (31\%) i siatkowa (30\%). Nieco rzadziej interesowano się gimnastyką (24\%), koszykówką (10\%), aerobikiem (6\%), piłką ręczną (4\%). Stwierdzono istotną statystycznie zależność między rodzajem szkoły $(\mathrm{p}=0,002)$, sytuacją materialną rodziny $(p=0,04)$, a częstością podejmowania ruchu. Wykazano, że licealiści znacznie rzadziej byli aktywni fizycznie niżeli gimnazjaliści czy uczniowie szkół podstawowych. Ankietowani, oceniający rodzinną sytuację materialną, jako bardzo dobrą byli aktywni fizycznie w znacznie większym stopniu $\mathrm{w}$ porównaniu z mniej zamożnymi badanymi. $\mathrm{Na}$ podejmowanie wysiłku fizycznego nie wpływały płeć $(p=0,29)$, miejsce zamieszkania $(p=0,10)$ i wartość współczynnika BMI $(\mathrm{p}=0,61)$ (tabela 1).

Kolejnym analizowanym zachowaniem zdrowotnym były zwyczaje żywieniowe. Ponad połowa (53\%) badanych spożywała regularnie 3-5 posiłków dziennie. Kolejne 29\% ankietowanych jadało taką samą liczbę posiłków, ale nieregularnie. Pozostali respondenci posilali się 1-2 (12\%) lub ponad 6 razy (5\%) na dobę. Nie wykazano istotnej statystycznie zależności między rodzajem szkoły $(p=0,08)$, płcią $(\mathrm{p}=0,16)$, miejscem zamieszkania $(\mathrm{p}=0,51)$, wartością współczynnika BMI $(\mathrm{p}=0,21)$, rodzinną sytuacją materialną $(\mathrm{p}=0,59)$, a liczbą dziennie spożywanych posiłków (tabela 2).

Jako kolejny omówiony zostanie skład pokarmowy spożywanych posiłków. W znaczącej części (86\%) respondenci spożywali mleko lub produkty mleczne w 1-2 posiłkach dziennie. Tylko 14\% przyznało, że są one składnikiem wszystkich dań. U blisko $2 /{ }_{3}(63 \%)$ badanych białko zwierzęce znajdowało się w 3-4 posiłkach dziennie. Warzywa i owoce były dostarczane głównie w 2-3 posiłkach (77\%). Około $2 / 3$ (64\%) badanych spożywało codzienne ciemne pieczywo lub grubą kaszę. Produkty typu fast-food konsumowano głównie raz w tygodniu $(77 \%)$.

Badanych poproszono o samoocenę dziennej diety, sporządzoną na podstawie analizy odpo- 
Tabela 1. Podejmowanie aktywności fizycznej w zależności od rodzaju szkoły i czynników socjo-demograficznych

\begin{tabular}{|c|c|c|c|c|}
\hline \multirow{2}{*}{$\begin{array}{c}\text { Zmienna } \\
\leq \text { raz tygodniowo }\end{array}$} & & \multicolumn{3}{|c|}{ Częstotliwość podejmowania aktywności fizycznej } \\
\hline & & $\leq$ raz tygodniowo & $\leq 3$ razy tygodniowo & $\geq 4$ razy tygodniowo \\
\hline \multicolumn{5}{|c|}{ Rodzaj szkoły } \\
\hline \multirow{2}{*}{ szkoła podstawowa } & $\mathrm{n}$ & 6 & 17 & 27 \\
\hline & $\%$ & 12 & 34 & 54 \\
\hline \multirow{2}{*}{ gimnazjum } & $\mathrm{n}$ & 6 & 9 & 34 \\
\hline & $\%$ & 12 & 18 & 70 \\
\hline \multirow{2}{*}{ liceum } & $\mathrm{n}$ & 11 & 25 & 15 \\
\hline & $\%$ & 22 & 49 & 29 \\
\hline \multicolumn{5}{|c|}{ Analiza statystyczna: $\mathrm{Chi}^{2}=16,91 ; p=0,002$} \\
\hline \multicolumn{5}{|c|}{ Płeć } \\
\hline \multirow{2}{*}{ dziewczęta } & $\mathrm{n}$ & 17 & 28 & 44 \\
\hline & $\%$ & 19 & 31 & 50 \\
\hline \multirow{2}{*}{ chłopcy } & $\mathrm{n}$ & 6 & 23 & 32 \\
\hline & $\%$ & 10 & 38 & 52 \\
\hline \multicolumn{5}{|c|}{ Analiza statystyczna: $\mathrm{Chi}^{2}=2,51 ; \mathrm{p}=0,29$} \\
\hline \multicolumn{5}{|c|}{ Miejsce zamieszkania } \\
\hline \multirow{2}{*}{ wieś } & $\mathrm{n}$ & 12 & 29 & 29 \\
\hline & $\%$ & 17 & 41,5 & 41,5 \\
\hline \multirow{2}{*}{ miasto } & $\mathrm{n}$ & 11 & 22 & 47 \\
\hline & $\%$ & 14 & 27 & 59 \\
\hline \multicolumn{5}{|c|}{ Analiza statystyczna: $\mathrm{Chi}^{2}=4,62 ; \mathrm{p}=0,10$} \\
\hline \multicolumn{5}{|c|}{ Wartość współczynnika BMI } \\
\hline \multirow{2}{*}{ prawidłowa masa ciała } & $\mathrm{n}$ & 18 & 38 & 58 \\
\hline & $\%$ & 16 & 33 & 51 \\
\hline \multirow{2}{*}{ nadwaga, otyłość } & $\mathrm{n}$ & 3 & 5 & 12 \\
\hline & $\%$ & 15 & 25 & 60 \\
\hline \multirow{2}{*}{ niedowaga } & $\mathrm{n}$ & 2 & 8 & 6 \\
\hline & $\%$ & 13 & 50 & 37 \\
\hline \multicolumn{5}{|c|}{ Analiza statystyczna: $\mathrm{Chi}^{2}=2,69 ; \mathrm{p}=0,61$} \\
\hline \multicolumn{5}{|c|}{ Sytuacja materialna } \\
\hline \multirow{2}{*}{ bardzo dobra } & $\mathrm{n}$ & 8 & 15 & 30 \\
\hline & $\%$ & 15 & 28 & 57 \\
\hline \multirow{2}{*}{ dobra } & $\mathrm{n}$ & 14 & 28 & 26 \\
\hline & $\%$ & 21 & 41 & 38 \\
\hline \multirow{2}{*}{ przeciętna } & $\mathrm{n}$ & 1 & 8 & 20 \\
\hline & $\%$ & 3 & 28 & 69 \\
\hline \multicolumn{5}{|c|}{ Analiza statystyczna: $\mathrm{Chi}^{2}=10,14 ; \mathrm{p}=0,04$} \\
\hline n - liczebność, \% - o & $\mathbf{p}-1$ & iom istotności statys & znej, $\mathbf{C h i}^{2}$ - wynik testu & hi-kwadrat \\
\hline
\end{tabular}


Tabela 2. Liczba spożywanych dziennie posiłków w zależności od rodzaju szkoły i czynników socjo-demograficznych

\begin{tabular}{|c|c|c|c|c|}
\hline \multirow{2}{*}{\multicolumn{2}{|c|}{ Zmienna }} & \multicolumn{3}{|c|}{ Liczba dziennie spożywanych posiłków } \\
\hline & & $1-2$ & $3-5$ regularne & $\geq 3$ nieregularne \\
\hline \multicolumn{5}{|c|}{ Rodzaj szkoły } \\
\hline \multirow{2}{*}{ szkoła podstawowa } & $\mathrm{n}$ & 9 & 29 & 12 \\
\hline & $\%$ & 18 & 58 & 24 \\
\hline \multirow{2}{*}{ gimnazjum } & $\mathrm{n}$ & 2 & 29 & 18 \\
\hline & $\%$ & 4 & 59 & 37 \\
\hline \multirow{2}{*}{ liceum } & $\mathrm{n}$ & 7 & 22 & 22 \\
\hline & $\%$ & 14 & 43 & 43 \\
\hline \multicolumn{5}{|c|}{ Analiza statystyczna: $\mathrm{Chi}^{2}=8,46 ; \mathrm{p}=0,08$} \\
\hline \multicolumn{5}{|c|}{ Płeć / Sex } \\
\hline \multirow{2}{*}{ dziewczęta } & $\mathrm{n}$ & 7 & 49 & 33 \\
\hline & $\%$ & 8 & 55 & 37 \\
\hline \multirow{2}{*}{ chłopcy } & $\mathrm{n}$ & 11 & 31 & 19 \\
\hline & $\%$ & 18 & 51 & 31 \\
\hline \multicolumn{5}{|c|}{ Analiza statystyczna: $\mathrm{Chi}^{2}=3,61 ; \mathrm{p}=0,16$} \\
\hline \multicolumn{5}{|c|}{ Miejsce zamieszkania } \\
\hline \multirow{2}{*}{ wieś } & $\mathrm{n}$ & 10 & 34 & 26 \\
\hline & $\%$ & 14 & 49 & 37 \\
\hline \multirow{2}{*}{ miasto } & $\mathrm{n}$ & 8 & 46 & 26 \\
\hline & $\%$ & 10 & 57,5 & 32,5 \\
\hline \multicolumn{5}{|c|}{ Analiza statystyczna: $\mathrm{Chi}^{2}=1,36 ; \mathrm{p}=0,51$} \\
\hline \multicolumn{5}{|c|}{ Wartość współczynnika BMI } \\
\hline \multirow{2}{*}{ prawidłowa masa ciała } & $\mathrm{n}$ & 16 & 58 & 40 \\
\hline & $\%$ & 14 & 51 & 35 \\
\hline \multirow{2}{*}{ nadwaga, otyłość } & $\mathrm{n}$ & 2 & 14 & 4 \\
\hline & $\%$ & 10 & 70 & 20 \\
\hline \multirow{2}{*}{ niedowaga } & $\mathrm{n}$ & 0 & 8 & 8 \\
\hline & $\%$ & 0 & 50 & 50 \\
\hline \multicolumn{5}{|c|}{ Analiza statystyczna: $\mathrm{Chi}^{2}=5,92 ; p=0,21$} \\
\hline \multicolumn{5}{|c|}{ Sytuacja materialna } \\
\hline \multirow{2}{*}{ bardzo dobra } & $\mathrm{n}$ & 8 & 30 & 15 \\
\hline & $\%$ & 15 & 57 & 28 \\
\hline \multirow{2}{*}{ dobra } & $\mathrm{n}$ & 8 & 36 & 24 \\
\hline & $\%$ & 12 & 53 & 35 \\
\hline \multirow{2}{*}{ przeciętna } & $\mathrm{n}$ & 2 & 14 & 13 \\
\hline & $\%$ & 7 & 48 & 45 \\
\hline \multicolumn{5}{|c|}{ Analiza statystyczna: $\mathrm{Chi}^{2}=2,79 ; \mathrm{p}=0,59$} \\
\hline n - liczebność, \% - & $\mathbf{p}-$ & tnośc & $\mathrm{j}, \mathbf{C h} \mathbf{i}^{2}$ - wynik tes & kwadrat \\
\hline
\end{tabular}


wiedzi z 6 pytań. Za każdą prawidłową odpowiedź ankietowani mogli uzyskać maksymalnie 1 punkt. Średnia ocena dziennej diety wyniosła 4,53 $\pm 1,30$ punktów $(\mathrm{Me}=5,00)$. Ponad połowa (54\%) respondentów uznała swoją dietę za przeciętną. Pozostali ankietowani ocenili ją nisko $(20,67 \%)$ bądź wysoko
$(25,33 \%)$. Nie stwierdzono istotnej statystycznie zależności między rodzajem szkoły, a samooceną dziennej diety $(\mathrm{p}=0,64)$. Uczniowie szkół podstawowych nieznacznie częściej uznawali dzienną dietę, jako wysoką w porównaniu z gimnazjalistami i licealistami (tabela 3).

Tabela 3. Samoocena dziennej diety w zależności od rodzaju szkoły

\begin{tabular}{|c|c|c|c|c|}
\hline \multirow{2}{*}{ Rodzaj szkoły } & \multicolumn{3}{c|}{ Samoocena dziennej diety } \\
\cline { 3 - 5 } & $\mathrm{n}$ & niska & przeciętna & wysoka \\
\hline \multirow{2}{*}{ szkoła podstawowa } & $\%$ & 10 & 24 & 16 \\
\hline \multirow{2}{*}{ gimnazjum } & $\mathrm{n}$ & 20 & 48 & 9 \\
\cline { 2 - 5 } & $\%$ & 11 & 59 & 18 \\
\hline \multirow{2}{*}{ liceum } & $\mathrm{n}$ & 10 & 28 & 29 \\
\cline { 2 - 5 } & $\%$ & 20 & 55 & 25 \\
\hline
\end{tabular}

Źródło: opracowanie własne.

Tabela 4. Samoocena dziennej diety w zależności od czynników socjo-demograficznych

\begin{tabular}{|c|c|c|c|c|}
\hline \multirow{2}{*}{ Zmienna } & & \multicolumn{3}{|c|}{ Samoocena dziennej diety } \\
\hline & & niska & przeciętna & wysoka \\
\hline \multicolumn{5}{|c|}{ Płeć } \\
\hline \multirow{2}{*}{ dziewczęta } & $\mathrm{n}$ & 12 & 53 & 24 \\
\hline & $\%$ & 14 & 60 & 26 \\
\hline \multirow{2}{*}{ chłopcy } & $\mathrm{n}$ & 19 & 28 & 14 \\
\hline & $\%$ & 31 & 46 & 22 \\
\hline \multicolumn{5}{|c|}{ Analiza statystyczna: $\mathrm{Chi}^{2}=6,94 ; \mathrm{p}=0,03$} \\
\hline \multicolumn{5}{|c|}{ Miejsce zamieszkania } \\
\hline \multirow{2}{*}{ wieś } & $\mathrm{n}$ & 15 & 39 & 16 \\
\hline & $\%$ & 21 & 56 & 23 \\
\hline \multirow{2}{*}{ miasto } & $\mathrm{n}$ & 16 & 42 & 22 \\
\hline & $\%$ & 20 & 52,5 & 27,5 \\
\hline \multicolumn{5}{|c|}{ Analiza statystyczna: $\mathrm{Chi}^{2}=0,43 ; \mathrm{p}=0,81$} \\
\hline \multicolumn{5}{|c|}{ Wartość współczynnika BMI } \\
\hline \multirow{2}{*}{ prawidłowa masa ciała } & $\mathrm{n}$ & 24 & 60 & 30 \\
\hline & $\%$ & 21 & 53 & 26 \\
\hline \multirow{2}{*}{ nadwaga, otyłość } & $\mathrm{n}$ & 5 & 10 & 5 \\
\hline & $\%$ & 25 & 50 & 25 \\
\hline \multirow{2}{*}{ niedowaga } & $\mathrm{n}$ & 2 & 11 & 3 \\
\hline & $\%$ & 12 & 69 & 19 \\
\hline \multicolumn{5}{|c|}{ Analiza statystyczna: $\mathrm{Chi}^{2}=1,77 ; \mathrm{p}=0,78$} \\
\hline \multicolumn{5}{|c|}{ Sytuacja materialna } \\
\hline \multirow{2}{*}{ bardzo dobra } & $\mathrm{n}$ & 15 & 24 & 14 \\
\hline & $\%$ & 28 & 45 & 27 \\
\hline \multirow{2}{*}{ dobra } & $\mathrm{n}$ & 10 & 43 & 15 \\
\hline & $\%$ & 15 & 63 & 22 \\
\hline \multirow{2}{*}{ przeciętna } & $\mathrm{n}$ & 6 & 14 & 9 \\
\hline & $\%$ & 21 & 48 & 31 \\
\hline \multicolumn{5}{|c|}{ Analiza statystyczna: $\mathrm{Chi}^{2}=5,34 ; \mathrm{p}=0,25$} \\
\hline \multicolumn{5}{|c|}{ n - liczebność, \% - odsetek, p - poziom istotności statystycznej, $\mathbf{C h i}^{2}$ - wynik testu Chi-kwadrat } \\
\hline
\end{tabular}


Stwierdzono istotne statystycznie zależności między płcią, a samooceną dziennej diety $(\mathrm{p}=0,03)$. Dziewczęta częściej uznawały dietę za wysoką w porównaniu $\mathrm{z}$ chłopcami. Brak istotnej statystycznie zależności między miejscem zamieszkania $(\mathrm{p}=0,81)$, wartością współczynnika BMI $(\mathrm{p}=0,78)$, sytuacją materialną rodziny $(p=0,25)$, a samoocena dziennej diety (tabela 4).

\section{Dyskusja}

W okresie dojrzewania młodzi ludzie stopniowo przejmują odpowiedzialność za własne zachowania zdrowotne oraz kształtują nawyki, które przez większość będą realizowane przez całe życie. Dlatego niezwykle istotne jest, aby za młodu krzewić, wspierać i pomagać młodym ludziom w przyjmowaniu prawidłowych postaw żywieniowych czy popularyzować ruch (Wagner i in., 2015; Milosavljević i in., 2015). Autorska analiza donosi, iż ankietowani stawiali mocno na aktywność fizyczną, jednocześnie wykazując przeciętny poziom zachowań żywieniowych.

Podstawowym wyróżnikiem racjonalnego odżywiania jest odpowiednia liczba i regularność posiłków. Instytut Żywności i Żywienia zaleca spożywanie 5 posiłków dziennie, w tym śniadania, drugiego śniadania, obiadu, podwieczorku i kolacji. W badaniach Kotyrby i Wróblewskiej (2014) aż 94\% uczniów szkół podstawowych spożywało dziennie zbyt małą liczbę posiłków. Podkreślono niedostateczną obecności nabiału i nadmiar mięsa w diecie respondentów. Całyniuk, Kiciak, Grochowska-Niedworok (2014) analizowali zachowania żywieniowe uczniów szkół o profilu sportowym. Uczniowie spożywali głównie ponad 5 posiłków dziennie $(60,2 \%)$, przy czym regularność posilania się deklarowało 83,9\% badanych. Fornal-Urban, Kęska, Dobosz, Nowacka-Dobosz (2008) donoszą, iż zalecane 4-5 posiłków spożywała blisko połowa badanej młodzieży. W autorskiej analizie ankietowani konsumowali przeważnie 3-5 posiłków dziennie, przeciętnie przestrzegając ich regularności (53\%). Na liczbę dziennie zjadanych posiłków nie wpływał rodzaj szkoły, płeć, miejsce zamieszkania czy rodzinna sytuacja materialna.

Najczęściej powtarzane przez Polaków błędy żywieniowe dotyczą nadmiaru tłuszczów zwierzęcych, węglowodanów prostych oraz niedoboru produktów mlecznych, owoców i warzyw w codziennej diecie (Chabros i in., 2008). Mazur i Małkowska-Szkutnik (2010) informują, iż odżywianie młodych ludzi jest często niezbilansowane, mało urozmaicone, nieregularne. Stefańska, Falkowska, Ostrowska (2012) uważają, że niezależnie od płci młodzież przejawia nieracjonalny sposób odżywiania. Racje pokarmowe gimnazjalistów cechują się niską podażą węglowodanów i błonnika pokarmowego, a wysoką białka. Zdaniem badaczy konieczne jest prowadzenie działań edukacyjnych, zwłaszcza z zakresu umiejętności doboru produktów, znajomości ich wartości kalorycznej, proporcji składników pokarmowych wśród młodych ludzi. Szczepańska i in. (2014) uważaja, iż dieta warunkuje rozwój emocjonalny i psychofizyczny młodych ludzi. Wpływa na skuteczność uczenia się i rzutuje na jakość życia w starszym wieku. Ocenie poddali zachowania żywieniowe młodzieży w wieku szkolnym z miast Górnego Śląska, które w dużej mierze uznano za błędne. Uczniowie spożywali średnio 4 posiłki dziennie. Badani codzienne konsumowali chleb razowy i kasze w 34,4\%, mleko i jego przetwory w 56,3\%, mięso w formie dania głównego w 61,3\%, warzywa i owoce odpowiednio w 61,4\% i 66,6\%. Do okazjonalnego spożycia produktów fast-food czy gotowych posiłków przyznało się odpowiednio 63,9\% i 49,7\% uczniów. Aleksandrov, Poriadina, Kotova, Ivanova (2014) donoszą, iż 2/3 badanej przez nich młodzieży posila się nieregularnie 3 razy dziennie lub rzadziej. Co trzecie dziecko spożywa niewystarczającą ilość warzyw i owoców, 11,8\% potraw mięsnych, 48,6\% produktów mlecznych. Na kilkakrotne w ciągu tygodnia spożycie produktów fast-food wskazało 19,5\% badanych. Nie stwierdzono istotnych różnic między miejscem zamieszkania i płcią, a sposobem żywienia rosyjskiej młodzieży. Na zachowania żywieniowe wpływały za to wartość współczynnika BMI i poziom wykształcenia rodziców. Dzieci o prawidłowej masie ciała, dobrze wykształconych rodzicach posilały się bardziej regularnie i racjonalnie. Z kolei Doku, Koivusilta, Raisamo, Rimpelä (2013) badali stopień realizacji zaleceń żywieniowych i ruchu wśród nastolatków z Ghany. Młodsi badani (12-15-lat) spożywali częściej owoce i warzywa w porównaniu z 16-18-latkami. Chłopcy byli bardziej skłonni do uczestnictwa w aktywności fizycznej niż dziewczęta. Prawdopodobieństwo częstego jedzenia śniadania było wyższe u młodzieży ze środowisk zamożnych. Zdaniem badaczy potrzebne są liczne interwencje w celu poprawy spożycia śniadań, owoców i warzyw oraz aktywności fizycznej celem zapobiegania chorobom zwyrodnieniowym wśród młodzieży. Kim i in. (2016) oceniali wpływ konsumowania poszczególnych elementów diety i stopnia regularności posiłków na wyniki w nauce wśród 12-18-latków z Korei. Badacze donoszą, iż wyniki w nauce są silnie uzależnione od nawyków żywieniowych. Pozytywny wpływ na osiągnięcia szkolne miało systematyczne jedzenie śniadania i spożywanie owoców oraz mleka, a negatywny konsumpcja napojów gazowanych, słodyczy, produktów instant i fast-food.

Istotnym elementem prawidłowo zbilansowanej diety jest częste spożywanie warzyw i owoców. Odpowiednio po $1 / 3$ ankietowanych przez Całyniuk i in. (2014) jadła warzywa i owoce 3-4 lub 1-2 razy dziennie. Z kolei najwięcej badanych (48\%) przez Marcysiak i in. (2009) deklarowało spożywanie warzyw i owoców 1-2 razy w ciągu dnia. Potwierdzenie tego znajdujemy w rezultatach badań własnych, gdzie warzywa i owoce były dostarczane głównie w 2-3 posiłkach (77\%). 
Blisko 1/4 uczniów w badaniach Pituchy i Metery (2013) wskazała na drastycznie małe spożycie nabiału, gdyż tylko trzy razy tygodniowo. Spośród przetworów mlecznych w codziennym jadłospisie młodzieży badanej przez Całyniuk i in. (2014) znalazło się mleko o zawartości tłuszczu 3,2\%, kefiry i jogurty, sery żółte, które spożywane były przeważnie kilka razy dziennie. Podobne rezultaty uzyskali Marcysiak i in. (2009), którzy wykazali, iż codziennie nabiał spożywało 53\% osób. Analiza autorska dostarcza dość pozytywnej oceny spożycia nabiału przez uczniów, gdyż w 86\% produkty mleczne konsumowane były w 1-2 posiłkach dziennie.

W zasadach racjonalnego odżywiania podkreśla się pozytywną rolę ciemnego pieczywa i grubych kasz, zwłaszcza jako źródło błonnika pokarmowego. W badaniach Całyniuk i in. (2014) ponad połowa ankietowanych spożywała ciemne pieczywo okazjonalnie, a tylko 1,1\% codziennie. Z kolei grube kasze w ogóle nie jadła połowa uczniów. Na bardzo rzadkie spożycie tych produktów wskazano także w analizie Ilow, Regulska-Ilow, Płonka, Biernat (2009). Ciemne pieczywo spożywało tylko 16\% dziewcząt i 6\% chłopców. W badaniach własnych uzyskano znacznie lepsze rezultaty, bo 2/3 osób spożywało codzienne ciemne pieczywo lub grubą kaszę.

Braithwaite i in. (2014) badali popularność pokarmów fast-food i wpływ tej żywności na wartość współczynnika BMI u dzieci w wieku 6-7 lat i młodzieży 13-14-latniej. Na częste i bardzo częste spożywanie dań typu fast-food wskazało odpowiednio 23\% i 4\% dzieci oraz 39\% i 13\% młodzieży. Częste konsumowanie fast-food wpływa zdaniem badaczy na wzrost wartości współczynnika BMI u młodych ludzi. W badaniach Pieszko-Klejnowskiej, Stankiewicz, Niedoszytko, Kozaneckiej, Łysiak-Szydłowskiej (2007) młodzież spożywała fast-food rzadko albo wcale $(84 \%)$. W analizie Kotyrby i Wróblewskiej (2014) blisko połowa dzieci konsumowała produkty tego typu raz w miesiącu. W opracowaniu Pituchy i Metery (2013) dania fast-food aż 40\% młodzieży spożywa średnio raz tygodniowo. Znacznie gorsze rezultaty osiągnięto w badaniach własnych, bowiem produkty typu fast-food spożywano w 77\% raz w tygodniu.

Kolejną kwestią jest częstotliwość spożycia mięsa, które zalecane jest 2-3 razy tygodniowo (Chabros i in., 2008). W badaniach Całyniuk i in. (2014) młodzież spożywała mięso głównie 3-4 razy w ciągu tygodnia. Zaś Pieszko-Klejnowska i in. (2007) donoszą, że aż $60 \%$ respondentów spożywało mięso codziennie. W badaniach własnych u 2/3 osób białko zwierzęce znajdowało się aż w 3-4 posiłkach dziennie.

Zdaniem Woynarowskiej, Mazur, Oblacińskiej (2015) zajęcia z wychowania fizycznego nie cieszą się popularnością w ostatnim czasie, co potwierdza rosnąca liczba zwolnień lekarskich z tych lekcji. W opinii Kozłowskiej, Kowalczyk, Marzec (2015) tylko 30\% dzieci i młodzieży podejmuje czynności ruchowe, których rodzaj, częstotliwość i intensywność zaspokajają potrzeby fizjologiczne organizmu. Według Bergiera (2012) aż 57\% dzieci i młodzieży jest nieaktywna fizycznie, albo wykonuje zbyt małą dawkę ruchu. Stan ten pociąga za sobą liczne konsekwencje zdrowotne, jak zwiększone ryzyko rozwoju miażdżycy, cukrzycy, otyłości, komplikacji sercowo-naczyniowych, zaburzeń psychicznych, depresji, lęków, obniżonego poczucia własnej wartości, uzależnień od alkoholu i narkotyków (Camero, Hobbs, Stringer, Taylor, 2012; Wang, Fu, Lu, Tao, Hao, 2014). Zasadne wydaje się zatem kształcenie ku wychowaniu fizycznemu młodzieży i rozpowszechnianie informacji o jego pozytywnym wpływie na organizm ludzki (Jakobsen, 2014). Lo i in. (2017) badali zależność między środowiskiem szkolnym, a aktywnym spędzaniem wolnego czasu wśród tajwańskich gimnazjalistów. Młodzież pochodząca z miasta, wykazująca aktywność fizyczną po szkole, o dobrze rozwiniętej przyszkolnej infrastrukturze sportowej osiągała znacznie lepsze wyniki w zakresie siły mięśni, wytrzymałości, elastyczności i składu ciała. W badaniach Jodkowskiej, Oblacińskiej, Tabaki (2014) tylko w 27,5\% młodzieży wykonywało zalecany dzienny wymiar aktywności ruchowej. Chłopcy byli znacznie bardziej aktywni $(\mathrm{p}<0,001)$ niż dziewczęta. Zdaniem badaczy niezdrowe zachowania zdrowotne coraz szerzej rozpowszechniają się wśród nastolatków, stając się czynnikiem ryzyka chorób przewlekłych. Dmitruk, Kunicka, Popławska, Hołub (2016) analizowali poziom aktywności fizycznej nastolatków ze szkół ponadgimnazjalnych w Białej Podlaskiej. Badacze uzyskali zadowalające wyniki, gdyż ankietowana młodzież w dużej mierze wykazywała wysoki poziom aktywności fizycznej. Seabra i in. (2013) oceniali różnice w podejmowaniu aktywności fizycznej w zależności od czynników socjo-ekonomicznych u portugalskich uczniów szkół podstawowych. Promocja ruchu powinna koncentrować się na dziewczętach, dzieciach otyłych, o niższym statusie socjo-ekonomicznym, gdyż wykazują zwykle niższy poziom aktywności fizycznej i czerpią mniejszą przyjemność z gier sportowych. Lubowiecki-Vikuk i Biernat (2015) donoszą, iż młodzi ludzie spędzają coraz częściej czas wolny na zajęciach sedenteryjnych. Badali poziom wolnoczasowej aktywności fizycznej młodzieży gimnazjalnej. W zorganizowanych formach sportu uczestniczyła połowa badanych, przy czym częściej $(\mathrm{p}<0,05)$ deklarowali je chłopcy $(57,2 \%)$ niż dziewczęta (44,3\%). Najpopularniejszymi formami ruchu były piłka nożna, biegi, piłka siatkowa, koszykowa, jazda na rowerze, pływanie, taniec, sztuki walki. Według badaczy konieczne jest tworzenie strategii promocji sportu dla wszystkich. W badaniach własnych ankietowani wykazali duże zainteresowanie aktywnością fizyczną. Młodzież ćwiczyła głównie 2-3 razy $(34 \%, n=51), 4-5$ razy $(30 \%, n=45)$ oraz $6-7$ razy $(21 \%, n=31)$ tygodniowo. Najczęściej podejmowaną formą ruchu była jazda na rowerze, spacery, 
bieganie, piłka nożna i siatkowa, gimnastyka, koszykówka. Na częstość podejmowania ruchu wpływały rodzaj szkoły $(\mathrm{p}=0,002)$ i sytuacja materialna rodziny $(p=0,04)$. Licealiści i osoby niezamożne wykazywały najmniejszą aktywność ruchową wśród badanej młodzieży.

\section{Wnioski}

1. Prawidłowe zachowania żywieniowe, jak regularność, jakość, liczbę posiłków dostosowanych do potrzeb organizmu oraz regularna aktyw- ność fizyczna mają nieodzowny wpływ na zdrowie, rozwój dzieci i młodzieży.

2. Ankietowani wśród realizowanych zachowań zdrowotnych stawiali mocno na aktywność fizyczną, na którą rzutowały rodzaj szkoły i sytuacja materialna rodziny.

3. Badani wykazywali przeciętny poziom zachowań żywieniowych. Jedli nieregularnie i nieracjonalnie, spożywali zbyt mało warzyw, owoców i nabiału, a za dużo mięsa. Dużą popularnością cieszyły się dania fast-food.

\section{Literatura:}

1. Aleksandrov, A.A., Poriadina, G.I., Kotova, M.B., Ivanova, E.I. (2014). The specificity of children and adolescent eating habits (data for schoolchildren in Moscow and Murmansk. Voprosy Pitaniia, 83(4), 67-74.

2. Ambroży, J., Bester, J., Czuchraj, W., Dostał, K., Dubiel, M. (2013). Nawyki żywieniowe oraz częstość spożycia wybranych produktów przez dzieci w wieku 10-13 lat zamieszkałe na terenach miejskich i wiejskich. Annales Academiae Medicae Silesiensis, 67(4), 231-237.

3. Bednarek, A., Bednarz, M. (2013). Zachowania zdrowotne chłopców i dziewcząt w młodszym wieku szkolnym. Medycyna Ogólna i Nauki o Zdrowiu, 19(3), 305-312.

4. Bergier, J. (2012). Studies and measurements of physical activity of the society. Annals of Agricultural and Environmental Medicine, 19(3), 329-331.

5. Braithwaite, I., Stewart, A.W., Hancox, R.J., Beasley, R., Murphy, R., Mitchell, E.A. (2014). Fast-food consumption and body mass index in children and adolescents: an international cross-sectional study. BMJ Open, 4(12), e005813. https://doi.org/10.1136/bmjopen-2014-005813

6. Całyniuk, B., Kiciak, A., Grochowska-Niedworok, E. (2014). Zachowania zdrowotne i żywieniowe uczniów szkół o profilu sportowym (z uwzględnieniem płci oraz wskaźnika BMI badanych) - doniesienie wstępne. Medycyna Ogólna i Nauki o Zdrowiu, 20(2), 186-191. https://doi.org/10.5604/20834543.1112236

7. Camero, M., Hobbs, C., Stringer, M., Taylor, E.L. (2012). A review of physical activity interventions on determinants of mental health in children and adolescents. International Journal of Mental Health Promotion, 14(4), 196-206. https://doi.org/10.1080/14623730.2012.752901

8. Chabros, E., Charzewska, J., Rogalska-Niedźwiedź, M., Wajszczyk, B., Chwojnowska, Z., Fabiszewska, J. (2008). Mała aktywność fizyczna młodzieży w wieku pokwitania sprzyja rozwojowi otyłości. Problemy Higieny i Epidemiologii, 89(1), 58-61.

9. Dmitruk, A., Kunicka, I., Popławska, H., Hołub, W. (2016). Relationship between diet and physical activity level in adolescents from post-grammar schools. Roczniki Państwowego Zakładu Higieny, 67(1), 37-44.

10. Doku, D., Koivusilta, L., Raisamo, S., Rimpelä, A. (2013). Socio-economic differences in adolescents' breakfast eating, fruit and vegetable consumption and physical activity in Ghana. Public Health Nutrition, 16(5), 864-872. https://doi.org/10.1017/S136898001100276X

11. Fornal-Urban, A., Kęska, A., Dobosz, J., Nowacka-Dobosz, S. (2008). Nawyki żywieniowe dzieci i młodzieży grających w szachy. Pediatric Endocrinology, Diabetes and Metabolism, 14(3), 187-191.

12. Ilow, R., Regulska-Ilow, B., Płonka, K., Biernat, J. (2009). Ocena zwyczajów żywieniowych licealistów z Oleśnicy. Bromatologia i Chemia Toksykologiczna, 42(3), 693-698.

13. Jakobsen, A.M. (2014). Are there differences in motives between participants in individual sports compared to team sports? LASE Journal of Sport Science, 5(2), 32-42.

14. Jodkowska, M., Oblacińska, A., Tabak, I. (2014). How well do Polish teenagers meet health behaviour guidelines? Przegląd Epidemiologiczny, 68(1), 65-70.

15. Kim, S.Y., Sim, S., Park, B., Kong, I.G., Kim, J.H., Choi, H.G. (2016). Dietary Habits Are Associated With School Performance in Adolescents. Medicine (Baltimore), 95(12), e3096. https://doi.org/10.1097/MD.0000000000003096

16. Kotyrba, J., Wróblewska, I. (2014). Analiza zachowań żywieniowych dzieci klas III - V szkoły podstawowej. Puls Uczelni, 8(3), 11-15.

17. Kozłowska. E., Kowalczyk, A., Marzec, A. (2015). Aktywność fizyczna i niektóre jej uwarunkowania wśród młodzieży licealnej. Journal of Education, Health and Sport, 5(9), 386-396.

18. Lo, K.Y., Wu, M.C., Tung, S.C., Hsieh, C.C., Yao, H.H., Ho, C.C. (2017). Association of School Environment and After-School Physical Activity with Health-Related Physical Fitness among Junior High School Students in Taiwan. International Journal of Environmental Research and Public Health, 14(1), 83. https://doi.org/10.3390/ijerph14010083. 
19. Lubowiecki-Vikuk, A.P., Biernat, E. (2015). Zorganizowane i niezorganizowane formy aktywności fizycznej młodzieży gimnazjalnej w czasie wolnym na tle czynników osobniczych i społeczno-środowiskowych. Problemy Higieny i Epidemiologii, 96(2), 448-457.

20. Marcysiak, M., Ciosek, A., Żywica, M., Prządak, E., Banasiewicz, D., Marcysiak, M., Zagroba, M., Ostrowska, B., Skotnicka-Klonowicz, G. (2009). Zachowania żywieniowe i aktywność fizyczna uczniów klas sportowych i ogólnych w Ustrzykach Dolnych. Problemy Pielęgniarstwa, 17(3), 216-222.

21. Mazur, J., Małkowska-Szkutnik, A. (2010). Wyniki badań HBSC 2010. Raport techniczny. Warszawa: Instytut Matki i Dziecka.

22. Milosavljević, D., Mandić, M.L., Banjari, I. (2015). Nutritional knowledge and dietary habits survey in high school population. Collegium Antropologicum, 39(1), 101-117.

23. Pieszko-Klejnowska, M., Stankiewicz, M., Niedoszytko, M., Kozanecka, I., Łysiak-Szydłowska, W. (2007). Ocena sposobu odżywiania się gimnazjalnej młodzieży zamieszkującej wieś i miasto. Pediatria Współczesna. Gastroenterologia, Hepatologia i Żywienie Dziecka, 9(1), 59-62.

24. Pitucha, A., Metera, A. (2013). Charakterystyka nawyków żywieniowych i aktywności fizycznej dziecka w wieku wczesnoszkolnym w Górze Puławskiej. Zeszyty Naukowe WSSP, 17, 67-85.

25. Seabra, A., Mendonça, D., Maia, J., Welk, G., Brustad, R., Fonseca, A.M., Seabra, A.F. (2013). Gender, weight status and socioeconomic differences in psychosocial correlates of physical activity in schoolchildren. Journal of Science and Medicine in Sport, 16(4), 320-326. https://doi.org/10.1016/j.jsams.2012.07.008

26. Stefańska, E., Falkowska, A., Ostrowska, L. (2012). Ocena sposobu żywienia młodzieży gimnazjalnej miasta Białegostoku o zróżnicowanym stopniu odżywienia. Roczniki Państwowego Zakładu Higieny, 63(4), 469-475.

27. Szczepańska, E., Szeja, N., Szymkiewicz, A., Kowalska, A., Lenard, B., Bulwicka, A. (2014). Eating behaviours of middle- and secondary-school pupils from the upper Silesian region in Poland. Roczniki Państwowego Zakładu Higieny, 65(4), 337-344.

28. Wagner, S., Banaszkiewicz, M., Andruszkiewicz, A., Strahl, A., Miler, A., Kubica, A. (2015). Zachowania zdrowotne i miejsce zdrowia w hierarchii wartości młodzieży. Medycyna Ogólna i Nauki o Zdrowiu, 21(3), 278-281. https://doi.org/10.5604/20834543.1165353

29. Wang, H., Fu, J., Lu, Q., Tao, F., Hao, J. (2014). Physical activity, Body Mass Index and mental health in Chinese adolescents: a population based study. The Journal of Sports Medicine and Physical Fitness, 54(4), 518-525.

30. Woynarowska, B., Mazur, J., Oblacińska, A. (2015). Uczestnictwo uczniów w lekcjach wychowania fizycznego w szkołach w Polsce. Hygeia Public Health, 50(1), 183-190. 